\title{
PERAN MEDIA MASSA NASIONAL DALAM POLITIK INTERNASIONAL
}

\author{
Nita Andrianti \\ Fakultas Komunikasi dan Multimedia \\ Universitas Mercu Buana Yogyakarta \\ Email:nietha_soulmate@yahoo.com
}

\begin{abstract}
In international politics, the mass media is not only a source of political information but also trigger the occurrence of political change. In general, the mass media has a specific tendency for reporting international coverage of the political events. In short, the media has a major role in the international political communication. Active involvement of the media have spawned the term "media diplomacy", the mass media as a channel in a diplomatic mission of a state against another state. As "media diplomacy", the mass media not only report diplomatic events, but also act as negosiator.Related to the media diplomacy that the media as one of the actors in the dynamic system of international relations. Indonesia's position in the system of international relations greatly influenced the mass media actors.
\end{abstract}

\begin{abstract}
Abstrak
Dalam politik internasional, media massa bukan hanya sumber informasi politik, tetapi juga kerap menjadi pendorong terjadinya perubahan politik. Secara umum media massa memiliki kecenderungan--kecenderungan tertentu dalam melakukan liputan pada peristiwa politik internasional. Dalam wujud yang lebih konkret, media memiliki peranan besar dalam komunikasi politik internasional.Keterlibatan aktif media ini telah melahirkan istilah "media diplomacy' artinya media massa sebagai saluran dalam menjalankan misi diplomasi sebuah negara tehadap negara lainnya. Sebagai "media diplomacy", media massa tidak hanya sekadar meliput peristiwa diplomatik, tetapi media massa harus memiliki sikap sebagai seorang negosiator.Terkait dengan media diplomacy bahwa media sebagai salah satu aktor dalam dinamika tata hubungan internasional. Posisi Indonesia dalam tata hubungan internasional sangat dipengaruhi aktor media massa tersebut.
\end{abstract}

Keywords: Mass Media, Internasional, Politic Communication, Diplomacy.

\section{PENDAHULUAN}

Media massa kerap diibaratkan sebagai matahari, memberikan sinar yang menerangi dunia, atau menyampaikan pesan yang merasuk ke dalam kalbu umat manusia, hingga memberi pencerahan. Dengan begitu media massa seolah memiliki posisi di luar kehidupan masyarakat. Media massa dianggap memiliki keunggulan yang menyebabkan mampu mempengaruhi alam pikiran khalayak, yang selanjutnya akan mengubah masyarakat (Siregar, 2000:171).

Pandangan ini belum tentu kesimpulan empiris, karena terlalu bercampur dengan harapan, kepercayaan semacam ini kiranya yang menyebabkan penguasa di berbagai negara fasis atau komunis menuntut terlalu berlebihan terhadap media massa, sekaligus akan sangat represif manakala media massa dianggap tidak segaris dengan kemauan penguasa negara. Konsep Pers atau jurnalisme pembangunan, dan prinsip perijinan yang 
dijalankan pemerintah, merupakan ikutan logis dari pandangan ini atau masyarakat yang begitu takut dengan muatan media massa yang dianggap dapat merusak warga, sehingga menginginkan media massa menjadi perpanjangan mimbar khutbah (Siregar, 2000:171).

Disisi lain bahwa independensi dan objektifitas pemberitaan (misalnya) merupakan kiblat media yang tidak pernah lurus, ketidaklurusan tersebut tentunya disebabkan suguhan berita yang sesuai dengan warna ideologi maupun kepentingan ekonomi politik media. Sementara itu, kajian isi media tidak lepas dari kerangka interpretasi yang berisikan konsep public sphere (ruang/ kawasan publik) yang diketengahkan oleh Habermas, media menempati posisi sentral yang berfungsi memasok dan menyebarluaskan informasi yang diperlukan untuk penentuan sikap, dan memfasilitasi pembentukan opini publik, dengan menempatkan dirinya sebagai wadah independen dimana isu-isu permasalahan umum bisa diperdebatkan. Dalam pandangan public sphere yang lebih dipentingkan adalah objektifitas intermedia bukan hanya objektifitas intramedia, objektifitas intermedia dimaknai sebagai penilaian dan konstruksi obyektif media massa terhadap realitas, terutama konstruksi oleh wartawan. Objektifitas intramedia dimaknai sebagai keobyektifan media dari pengaruhpengaruh pemilik media, penguasa, dan lainnya. Intinya sulit untuk mengharapkan agar setiap media dalam membuat pemberitaan dapat objektif dan tidak memihak (Sudibyo, 2001: viii).

Jika dikaitkan dengan politik internasional, maka dapat dikatakan bahwa media dan politik Internasional merupakan dua entitas yang tidak dapat dipisahkan dalam kehidupan modern, keduanya saling berbagi peran dalam menentukan arah perubahanperubahan di masyarakat. Hubungan ini dipengaruhi oleh peran besar media massa dalam menentukan derajat keharmonisan dunia internasional, baik dalam hubungan bilateral maupun multilateral dalam kancah perpolitikan internasional melalui wacana politik yang dipublikasikan kepada khalayak.
Bagi politik internasional, aktifitas media berperan dalam melaporkan serta memberitakan peristiwa-peristiwa politik, kemudian peristiwa tersebut disampaikan kepada khalayak, untuk selanjutnya publik atau khalayak akan menafsirkan teks teks berita yang tersaji dalam media tersebut.

Kebijakan negara dan isu-isu dunia internasional disajikan media massa melalui berita politiknya, sehingga memiliki pengaruh sangat besar terhadap warga negara dalam berbagai bidang. Dinamika ini membuat media massa melalui isi berita yang dimunculkannya, memiliki beberapa unsur untuk diketahui, dintaranya unsur ketegangan, konflik kepentingan, aspek dramatik dalam setiap peristiwa melibatkan berbagai kebijakan dan isu-isu yang dimunculkan. Aspek-aspek demikian itu, sudah cukup alasan bagi media massa untuk menjadikannya sebagai laporan jurnalistik. Tokoh-tokoh politik yang terlibat didalamnya adalah mereka yang dikategorikan pejabat penting atau orang yang berperan penting dalam sebuah negara (Wahyuni, 2006:11) hingga menjadikannya layak untuk dijadikan berita.

Hubungan ini membuat adanya suatu sistem politik internasional yang dilakukan oleh para pejabat diplomatik (termasuk politik luar negeri suatu negara) dengan media massa saling pengaruh-mempengaruhi, ini terlihat dari beberapa hal ditandai dalam bentuk kebijakan politik sebuah negara, dalam menentukan pola operasi media massa di negara itu, mulai dari kepemilikan, tampilan isi, hingga pengawasannya. Revolusi komunikasi yang dijalankan media massa, menjadikan penempatan posisinya menjadi penting, karena media massa sebagai jembatan untuk menyampaikan pesan-pesan yang dapat memfungsikan kekuasaan, sedangkan para pejabat memberi informasi kepada pers untuk disampaikan kepada khalayak.

Dalam konteks saling pengaruh mempengaruhi, tentu media massa memiliki peranan dalam membentuk masyarakat internasional, bahkan lebih jauh media massa ikut serta melakukan perubahan-perubahan politik di level internasional. Untuk itulah kajian ini dibuat guna mengetengahkan 
peranan media massa pada level hubungan internasional, khususnya media massa nasional Indonesia.

\section{PEMBAHASAN}

\section{Relasi Media Massa-Politik Internasional}

Media dalam konteks ini bukan hanya sumber informasi politik, tetapi juga kerap menjadi pendorong (trigger) terjadinya perubahan politik. Secara umum media massa memiliki kecenderungan-kecenderugan tertentu dalam melakukan liputan pada peristiwa politik internasional. Pada posisi seperti inilah, kemudian media massa ditempatkan sebagai kekuatan keempat (the fourth estate) dalam tatanan kehidupan sosial dan politik. Media berfungsi sebagai pengendali sekaligus melakukan kontrol sosial bagi kepentingan publik.

Menurut pandangan Muhtadi (1999:48) bahwa media massa merupakan salah satu kekuatan sosial yang menjalankan kontrol sosial secara bebas dan bertangungjawab, baik terhadap masyarakat maupun terhadap kekuatan-kekuatan sosial politik lainnya. Efektifitas pengaruhnya dapat dilihat dari fakta-fakta sejarah, yang menyiratkan terjadinya perubahan perilaku politik yang signifikan sebagai akibat dari terpaan media massa. Runtuhnya kekuasaan Orde baru di Indonesia dan kemenangan Barack Obama dalam pemilihan presiden di Amerika Serikat adalah bukti perubahan politik yang tidak lepas dari peran sosial politik yang dimainkan oleh media massa.

Graber (1984:222) menyebutkan sekurang-kurangnya terdapat empat fungsi media massa bagi negara atau kekuasaan internasional, yaitu: pertama, media massa menyediakan informasi terbaru tentang berbagai peristiwa politik yang tengah berkembang di masyarakat dan dijadikan salah satu bahan pertimbangan bagi negara dalam membuat kebijakan-kebijakannya. Kedua, media massa memberikan ruang kesadaran sosial bagi negara untuk membaca lebih jauh opini publik yang berkembang di masyarakat. Ketiga, media massa juga mem- fasilitasi negara untuk dapat menyampaikan pesan-pesan kepada kekuasaan politik dan masyarakat umum, baik di dalam maupun di luar pemerintahan. Keempat, media massa memberikan kesempatan para penyelenggara negara untuk memelihara kontinuitas kekuasaannya di tengah peranannya.

Menurut Harsono Suwardi (2004: xvxvi) bahwa banyak aspek dari media yang membuat dirinya penting dalam kehidupan politik, pertama, daya jangkaunya (coverage) yang sangat luas dalam menyebarluaskan informasi publik, yang mampu melewati batas wilayah (geografis), kelompok umur, jenis kelamin,sosial-ekonomi-status (demografis), perbedaan paham dan orientasi (psikografis); dengan begitu suatu masalah politik yang dimediasikan menjadi perhatian bersama diberbagai tempat dan kalangan;

Kedua, kemampuan melipatgandakan pesan(multiplier of massage) yang luar biasa; suatu peristiwa politik bida dilipat gandakan pemberitaaanya sesuai dengan jumlah eksemplar koran, tabloid, dan majalah yang tercetak juga bisa diulang-ulang penyiarannya sesuai kebutuhan. Alhasil pelipat gandaan menimbulkan dampak yang sangat besar ditengah khalayak.

Ketiga, setiap media massa bisa mewacanakan sebuah peristiwa politik sesuai pandangannya masing-masing; kebijakan redaksional yang dimilikinya menentukan penampilan isi peristiwa politik yang diberitakan, justru karena kemampuan inilah media banyak diincar oleh pihak-pihak yang ingin menggunaan dan sebaliknya dijauhi oleh pihak-pihak yang tidak menyukainya;

Keempat, tentu saja fungsiagenda setting yang dimilikinya, media memiliki kesempatan yang sangat luas (bahkan hampir tanpa batas) untuk memberitakan peristiwa politik. Sesuai dengan kebijakannya masingmasing, setiap peristiwa politik dapat disiarkan atau tidak disiarkan, yang jelas belum tentu berita politik yang menjadi agenda media merupakan agenda publik juga;

Kelima, pemberitaan peristiwa politik oleh suatu media lazimnya berkaitan dengan media lainya hingga membentuk rantai 
informasi (media as a links in other chains). Hal ini menambah kekuatan tersendiri pada penyebaran informasi politik dan dampaknya terhadap publik, dengan adanya aspek ini semakin kuatlah peranan media dalam membentuk opini publik.

Pandangan lain menyebutkan bahwa, dalam negara modern, hubungan antara media massa dengan sistem politik sangat bergantung pada budaya politik, termasuk ideologi dan komunikasi politik. Baik media massa maupun sistem politik tidak terlepas dari kepentingan serta kecenderungan atau keberpihakan kepada sesuatu nilai baik yang berakar pada budaya. Hal ini seiring dengan pendapat Smythe, tentang adanya relasi dialektik antara praktek komunikasi bermedia-nonmedia dan konstruksi sosial-politik dalam masyarakat (Wahyuni, 200o: 198).

Intinya secara garis besar sebenarnya ada dua model hubungan kekuasaan dengan negara pada media yaitu, pertama, model dominasi yang dilakukan dinegara negara otoriter, dimana media dimanfaatkan secara terang-terangan sebagai alat instruksi, peringatan dan kontrol langsung.Kedua, model pluralisme yang dijalankan oleh negara negara demokrasi liberal, dimana media massa lebih bebas untuk mengekspresikan diri, karena negara tidak terlalu turut campur tangan dalam urusan media.

Kondisi demikian membuat peran media dalam memberitakan wacana politik dapat dipandang sebagai penyampai pesan politik, seperti yang disampaikan Hennessy (1975: 1) bahwa media massa sebagai saluran komunikasi politik yang memuat berita mengenai kunjungan diplomatik, serta kebijakan-kebijakan yang dibuat, menjadikan ini sebagai proses pengemasan pesan yang menarik perhatian ditingkat nasional maupun internasional. Media massa memiliki kekuatan tersendiri dalam mempengaruhi sistem politik, sehingga hubungan keduanya biasanya ditandai dengan (Hamad, 2004: 7-8):

Pertama, bentuk dan kebijakan politik sebuah negara menentukan pola operasi media massa di negara itu, mulai dari kepemilikan, tampilan isi, hingga pengawasannya. Begitu dominannya sistem politik (pemerin- tah) mempengaruhi sistem media, sehingga kondisi demikian ini mendorong orang untuk membuat kesimpulan bahwa sistem media yang berlaku di sebuah negara menjadi cerminan sistem politik (rezim) negara itu;

Kedua, media massa sering menjadi media komunikasi politik terutama bagi penguasa, tradisi jurnalistik justru dimulai dengan adanya kepentingan para raja menyebarluaskan maklumat-maklumat kekuasaannya, dan pada masa-masa berikutnya, setiap kekuasaan selalu bersentuhan dengan media massa demi kepentingan politik. Dalam dunia politik modern media bahkan telah menjadi keniscayaan, juga untuk bermacam kepentingan. Setiap kekuatan politik sedapat mungkin memakai media massa untuk melancarkan hajat politiknya. Dalam hubungan jenis kedua ini, tak selamanya media massa ditentukan oleh sistem politik (rezim), tetapi tergantung pada persebaran kekuasaan (power sharing) yang terjadi di negara itu, di dalam negara setiap kelompok sosial memiliki kesempatan yang sama terhadap media, maka media massa dapat menjadi saluran komunikasi politik untuk mempengaruhi sistem politik (rezim)

Keterkaitan sistem politik internasional (termasuk politik luar negeri suatu negara) dengan media massa adalah saling pengaruh-mempengaruhi, bahwa media massa merupakan subsistem dari sistem politik yang lahir dari sejarah politik tertentu, namun media massa memiliki kekuatan sendiri dalam mempengaruhi sistem politik, sehingga keterkaitan keduanya dapat ditandai dari beberapa hal, yaitu:

Satu, bentuk dan kebijakan politik sebuah negara menentukan pola operasi media massa di negara itu, mulai dari kepemilikan, tampilan isi, hingga pengawasannya. Begitu dominannya sistem politik mempengaruhi sistem media, sehingga kondisi demikian ini mendorong orang untuk membuat kesimpulan, bahwa sistem media massa yang berlaku di sebuah negara menjadi cerminan sistem politik (rezim) negara itu (Denis McQuails, 1996:121-153). Dua, media massa sering menjadi media komunikasi politik terutama oleh penguasa, tradisi jur- 
nalistik justru dimulai dengan adanya kepentingan para raja dalam menyebarluaskan maklumat-maklumat kekuasaan. Pada masa berikutnya, setiap kekuatan politik sedapat mungkin memakai media massa untuk melancarkan kegiatan politiknya.

Proses ini dapat dilihat dalam berbagai sisi, seperti satu; peranan media massa memperlakukan kehidupan politik, termasuk aktivitas dan dinamika pemerintah dalam peliputannya. Seperti kunjungan diplomatik dilakukan oleh pejabat negara yang berkunjung ke Indonesia, dalam rangka mendiskusikan kerjasama di berbagai bidang.Dua, peranan media massa nasional dalam kancah internasional adalah melakukan liputan-liputan tentang interaksi negaranegara dalam kancah internasional, misalnya politik Amerika, Eropa, Asia, dalam menilai demokrasi internasional. Keterlibatan sebuah negara dalam berbagai forum internasional, hubungan multilateral, dan bilateral antara satu negara dengan negara lainnya, mampu memberikan dukungan, kritik, bahkan bersikap netral, semisal liputan New York Times, The Jakarta Post, Kompas, Media Indonesia dan media massa lainnya terhadap kunjungan diplomatik pejabat negara yang berkunjung ke Indonesia.

Menurut Kepala Departemen Jurnalistik New York University Jay Rosen terdapat dimensi relasi antara media dan politik: Satu, media dapat menjadi ruang publik bagi terjadinya interaksi politik, ikut mempengaruhi pembentukan sistem komunikasi politik di kalangan publik, pembentukan karakter dan agenda politik berlangsung secara terbuka. Dua, media tidak hanya menjadi cermin dari kehidupan politik, tetapi melakukan generalisasi realitas politik, mengkonstruksi realitas politik sebagai sesuatu yang bersifat kompleks dan mengundang antusiasme respon publik.

Tiga, konstruksi realitas media atas dunia politik itu secara positif akan memperkuat komitmen pencapaian tujuan politik ideal dari partai politik atau politisi dan kontrol publik yang tajam atas proses itu. Sayangnya ilustrasi relasi media dan politik versi Meyer ini terlampau ideal dan mengalami banyak kendala kultural dan struktural ketika diterapkan. Sementara Bill Kovach mengemukakan jurnalisme dan demokrasi tumbuh bersama-sama, demokrasi tidak akan eksis tanpa jurnalisme politik yang baik, jurnalisme gosip, rumor, jumalisme yang bercampur dengan hiburan, atau jurnalisme yang menjadi propaganda politik akan meracuni (Masduki, 2004: 77)

Dalam sisi yang lain, Murdock dan Golding (1989:183-184) melihat adanya tiga jenis hubungan antara komunikasi dan kewarganegaraan: Satu, orang harus punya akses pada informasi, nasehat-nasehat dan analisis yang memungkinkan mereka untuk mengetahui hak-hak mereka di ruang lain dan memungkinkan mereka untuk mencapai hak ini secara efektif. Dua, mereka harus punya akses kepada kemungkinan jangkauan atau cakupan informasi yang paling luas, interpretasi dan debat pada bidang-bidang yang melibatkan pilihan politis dan mereka harus mampu menggunakan fasilitas komunikasi dalam usaha untuk melakukan kritik, memobilisasi oposisi dan menawarkan alternatif tindakan. Tiga, mereka harus mampu mengetahui diri mereka dan aspirasi mereka dalam beragam perwakilan yang ditawarkan dalam sektor komunikasi penting dan mampu menyumbang pengembangan perwakilan-perwakilan tersebut.

Perkembangan selanjutnya adalah penguatan komunikasi politik era modern, bahwa dalam perspektif komunikasi politik demokratis, media massa dalam fungsinya sebagai infrastruktur politik berperan sebagai media komunikasi politik (media of political communication). Kinerja media sebagai media komunikasi politik ini, jelas menuntut kualitas standar kelompok wartawan (journalism group) yang berada di balik media massa. Khususnya melalui berita-berita politik yang ditulis oleh kelompok wartawan inilah diharapkan terjadi proses pendidikan politik bagi masyarakat, agar siap menyongsong demokrasi yang dicita-citakan. Intinya, media massa dalam komunikasi politik negara demokrasi harus menjamin terwujudnya keberagaman opini dalam masalah-masalah yang menyangkut kepentingan publik. Da- 
lam perspektif komunikasi politik yang demokratis inilah, akan dilihat peluang dan hambatan bagi media Indonesia untuk merealisasikan dirinya sebagai bagian dari infrastrukrur politik (Wahyuni, 2000: 201).

Uraian di atas muncul keterkaitan media massa dengan komunikasi politik internasional, yaitu: Satu, bahwa media massa lahir dari rahim politik nasional, sehingga wajar jika representasi media massa terkait dengan keberadaan negara tempat lahirnya media massa tersebut, misalnya lahir berbagai media yang mencerminkan tempat kelahirannya seperti: New York Times, Washington Post, Media Indonesia, dan yang lebih ekstrim lahir istilah "Pers Pancasila" di Indonesia, sehingga dalam kancah internasional bahwa media massa merupakan representasi negara yang memperjuangkan kepentingan nasional negara tersebut, sehingga dalam hubungan diplomatik atau berita kunjungan diplomatik maka wajar jika media massa memberikan dukungan maupun kritik terhadap penilaian apakah kunjungan diplomatik itu bermanfaat atau merugikan kepentingan nasional negara tertentu. Dua, Peranan media massa ini lazimnya memberitakan peristiwa-peristiwa yang terjadi dalam interaksi internasional, bisa memberikan dukungan, memberikan kritik dan bahkan bersikap netral, semisal liputan New York Times, The Jakarta Post, Kompas, Media Indonesia dan media massa lainnya terhadap kunjungan diplomatik Presiden Obama ke Indonesia.

\section{Peran Media Massa dalam Praktik Komunikasi Politik Internasional}

a. Media Massa sebagai Aktor Politik

Masyarakat mengetahui perilaku politik dari berbagai media massa, bahkan dapat dikatakan bahwa masyarakat sangat mengandalkan media massa dalam memperoleh informasi peristiwa-peristiwa politik yang terjadi di tingkat nasional maupun internasional. Ketergantungan masyarakat atas informasi terhadap media massa, menjadi sasaran tembak paling tepat bagi pemerintah/negara dalam dunia internasional untuk menyebarkan kebijakan publik dan isu-isu politik yang berpengaruh terhadap perubahan sosial dan politik di masyarakat.

Peristiwa politik seperti kunjungan diplomatik selalu menarik perhatian media massa sebagai bahan liputan, hal ini lazimnya disebabkan oleh beberapa faktor, yaitu: pertama, dewasa ini politik berada di era mediasi (politics in the age of mediation), yakni media massa, sehingga hampir mustahil kehidupan politik dipisahkan dari media massa, malahan para aktor politik senantiasa berusaha menarik perhatian wartawan agar aktifitas politiknya memperoleh liputan dari media, misalnya kebijakan hak asasi manusia Amerika Serikat masa kepemimpinan Clinton yang menyebabkan media massa juga ikut gencar memberitakan isu-isu hak asasi manusia di Indonesia (Cipto, 2003:131). Kedua, peristiwa politik dalam bentuk tingkah laku dan pernyataan para aktor politik lazimnya selalu mempunyai nilai berita, misalnya pernyataan Presiden Clinton tentang terjadinya pelanggaran hak asasi manusia di Timor Timur yang diliput oleh hampir seluruh media massa di Amerika.

Menurut McNair (1995:2-15) bahwa politik di era mediasi (politics in the age of mediation) ketika dikaitkan dengan fungsi media dan media massa dalam komunikasi politik bisa menjadi penyampai (transmitters) pesan-pesan politik dari pihak-pihak di luar dirinya, sekaligus menjadi pengirim (senders) pesan-pesan politik yang disusun (constructed) oleh pers. Para aktor politik oleh media massa dipakai untuk menyampaikan pesan-pesan politik mereka kepada khalayak, sementara untuk media massa sebagai aktor dalam era politik mediasi bertugas untuk memproduksi pesan-pesan politik berdasarkan suatu jangkauan (coverage) tertentu (Hamad, 2005). Artinya hal tersebut mampu memberi pencapaian dan keuntungan dari kedua belah pihak, yakni dari sisi media massa dan para pejabat negara, termasuk pejabat diplomatik.

Menurut Kepala Departemen Jurnalistik New York University Jay Rosen dalam tradisi jurnalisme politik, media adalah pemain (player), subjek aktif di ruang publik bukan sekedar medium atau alat yang dikendali- 
kan pihak diluar pengelola media itu (Rosen, 2004). Sebagai pemain tentu berfungsi sebagai agen perubahan (agent of change) pada level internasional dengan menggunakan caranya sendiri, yakni melalui publikasi berita politik yang menjadi agenda politiknya. Sebuah media massa yang pro terhadap pemerintah tentu akan memberitakan berita politik yang menguntungkan pemerintah yang berkuasa dan sebaliknya.

Menurut Wirajuda (2003) bahwa dalam dinamika tata hubungan internasional akan di pengaruhi sejumlah isu-isu umum dan khusus serta beragam aktor pemerintah dan non pemerintah, salah satunya adalah media massa. Pandangan Nunung Prajarto (2003:4) dalam konteks hubungan internasional, berita-berita tentang kebijakan luar negeri suatu negara mestinya ditujukan untuk konsumsi luar negeri (external public relations), yang arahnya menginginkan terbentuknya citra positif Indonesia di luar negeri. Pemanggul beban yang lebih tepat adalah media massa asing atau media massa Indonesia yang berbahasa asing. Bahasa yang digunakan dalam media massa ini menjadi penting, dalam tataran ontologis, bahasa sebagai alat untuk mengetahui segala sesuatu yang ada, termasuk juga politik. Maka semakin disadari bahwa bahasa adalah produk zaman.Komulasi ekspresi kebudayaan atau "wakil' sebuah kekuasaan. Media massa merupakan sarana penyebarluasan berita dan informasi kepada khalayak luas, baik secara lokal, nasional, maupun internasional.

Hal ini selaras dengan fungsi media massa sebagai lembaga siaran yang berkepentingan dengan penyebaran informasi dan bisnis serta upaya mempengaruhi opini publik internasional (Shoelhi, 2009). Di mana dikatakan oleh Marshall McLuhan mengenai global village, yang membuat batas antar negara tidak jelas.Dengan memanfaatkan kemajuan di bidang teknologi telekomunikasi yang telah berkembang dengan pesat, maka seluruh bangsa-bangsa di dunia dapat disatukan dalam agenda globalisasi.

Sementara, media massa di negara lain/ asing yang jangkauannya domestik tidak begitu relevan, tentu kurang memperngar- uhi kebijakan pemerintah Indonesia dalam berbagai bidang, namun media massa besar di negara tertentu (AS, Jepang, Inggris, Malaysia) yang memiliki jangkauan internasional seperti $C N N, V O A, B B C$, Time, Herald Tribune, mau tidak mau perlu dikaji serta dipertimbangkan opini dan ulasannya oleh pemerintah Indonesia. Sebab pengaruh media massa yang memiliki jangakauan dunia internasional (tidak hanya domestik/ nasional) memiliki pengaruh pembentukan opini publik di kalangan Pemerintah dan masyarakat di berbagai negara di dunia. Media massa dapat bersikap mendukung atau bahkan mengkritisi kebijakan politik suatu negara terkait kunjungan diplomatik. Media massa sebagai salah satu aktor dalam dinamika tata hubungan internasional, dan posisi Indonesia dalam tata hubungan internasional sangat dipengaruhi oleh hal tersebut (Prajarto, 2003:1).

Jika merujuk pada pemahaman bahwa media massa merupakan aktor perubahan politik, tentu hal ini dapat ditelisik dari ideologi media yang tertuang jelas dalam berbagai agenda media. Warna agenda politik media massa sangat ditentukan oleh kepentingan internal media, yang lebih lanjut informasi yang diberitakan juga tidak terlepas dari kepentinganya tersebut.

Bahkan secara lebih nyata terdapat media massa yang menempatkan sebagai opisisi pemerintahan yang berita-beritanya memberikan kritik-penyeimbang terhadap berbagai kebijakan pemerintah. Dengan berdasar pada isi berita tersebut, maka peristiwa politik yang dianggap penting dijadikan agenda media untuk disampaikan kepada khalayak (Rivers-Jenson, 2004:38, Tankard, 2009: 388). Karena media massa ditempatkan sebagai salah satu kekuatan penting yang ada ditengah masyarakat, dalam menjamin adanya checks and balance dari berbagai kekuasaan, maka peranan media massa harus mampu melahirkan laporan-laporan yang valid berdasarkan data dan fakta yang terjadi di lapangan.

Media massa sebagai aktor dalam kehidupan sosial politik, juga ikut berkecimpung dalam menciptakan perubahan-pe- 
rubahan sosial dan politik (agent of change) yang terjadi melalui berita-berita yang dipublikasikan. Sebagai agen perubahan (agent of change) media massa menggunakan caranya sendiri, yakni melalui publikasi berita politik yang menjadi agenda politiknya. Sebuah media massa yang pro terhadap pemerintah tentu akan memberitakan berita politik yang menguntungkan pemerintah yang berkuasa dan sebaliknya.

Merujuk pada pandangan Nimmo (2004:236) bahwa jumlah berita politik disajikan oleh media massa merupakan proses yang bertalian dengan hubungan antara penguasa dan media.Penyajian kepada khalayak dalam bentuk urutan pilihan kebijakan dan dicapai dalam isi berita mengenai; mana yang harus disajikan terlebih dahulu; berapa banyak ruang dan waktu yang disediakan bagi masing-masing; dimana meletakan masing-masing berita (halaman pada surat kabar).Sebagai aktor politik, tentu peranan media massa memiliki ranah tersendiri, yakni berita-berita politik yang disajikan tidak terlepas dari kepentingan media (agenda politik media).

Lebih lanjut agenda politik media berimplikasi adanya agenda setting (urutan prioritas terhadap peristiwa politik internasional yang dinilai penting) juga berimplikasi pada adanya media event.Media event merupakan suatu peristiwa atau kegiatan yang memiliki tujuan khusus untuk publisitas media. Hal ini juga dapat mencakup setiap peristiwa yang diliput oleh media massa atau diselenggarakan terutama yang telah menjadi agenda media. Media event as: certain situated, thickened, centring performances of media communication focused on a specific thematic core, cross different media product and a reach a wide and diverse multiplicity of audience and participant". Berita sebagai media event, seperti peristiwa gejolak politik, bencana, dan peristiwa-peristiwa yang menyita perhatian publik.

Dalam pandangan Hermin Indah Wahyuni (2006:5), bahwa peristiwa sebagai media event setidaknya memiliki basis penilaian yang dilakukan mengenai nilai berita yang dipilih.Beberapa nilai berita diantaran- ya adalah signifikan, keterkenalan, kedekatan, kemanusiaan dan lainnya.Jika hal ini dikaitkan dengan genesis media yang beroperasi dalam prinsip bisnis, maka pelaporan peristiwa kunjungan diplomatik pada aspekaspek yang terkait dengan fakta-fakta berpotensi untuk dikomersilkan.Oleh karenanya tidak aneh bila liputan media tidak saja berdampak positif, namun juga berdampak negatif bagi masyarakat.

Media massa akan melihat peristiwa hubungan internasional yang penting dan layak untuk dijadikan berita lazimnya praktik ini dikenal dengan media event. Praktek media event terkait dengan kecenderungan studi mengenai proses produksi berita, pada pendekatan pertama sering disebut sebagai pandangan seleksi berita (selectivity of news). Intinya proses produksi berita merupakan proses seleksi berita dari realitas yang riil untuk kemudian diseleksi oleh wartawan selanjutnya dibentuk dalam sebuah berita. Sedangkan pendekatan kedua yakni pendekatan pembentukan berita (creations of news), dalam perspektif ini peristiwa tersebut bukan diseleksi melainkan dikreasi oleh wartawan. Artinya berita merupakan hasil akhir dari keseluruhan proses dengan memilah dan menentukan peristiwa atau tema tertentu (Fishman, 1980:13-14), untuk kemudian hasil ciptaan tersebut dipublikasikan kepada khalayak.

Media event merupakan cara media massa mengatur beritanya sedemikian rupa. Artinya bahwa media event adalah "kemasan model" berpolitiknya media massa, sehingga khalayak (audience) dapat menilai bahwa berita itu dianggap sebagai isu yang penting dan hangat, atau kejadian mengenai isu yang dipandang penting oleh redaksi suatu media massa.Pemberitaan oleh redaksi menggambarkan pentingnya berita tersebut, misalnya dijadikan pokok berita, headline, dan diulang-ulang (A.Muis, 2000:v). Artinya, media event merupakan peristiwa menarik (journalistic point of view) yang menjadi sorotan media untuk dijadikan sebagai agenda media, yang dalam hal ini peristiwa tersebut direncanakan atau spontan.Pada akhirnya diseleksi apabila menarik cakupan berita 
tersebut.

Liputan peristiwa internasional sebagai event menarik, merupakan bentuk partisipasi dan peran media massa dalam pelaksanaan hubungan luar negeri Indonesia dengan negara lain dan membantu masalah-masalah internasional. Artinya, media massa merupakan bagian yang tidak terpisahkan dari diplomasi internasional (diplomasi publik). Misalnya, untuk meredakan ketegangan internasional, menyelesaikan konflik dengan memberitakan harapan-harapan negara yang satu dengan negara lainnya (Wirawan, 2008:11).

Bagi media massa di Indonesia, posisi media dalam meliput kunjungan diplomatik harus mendasarkan pada politik luar negeri Indonesia. Misalnya, isi media mau tidak mau harus merefleksikan bahwa politik Indonesia adalah bebas aktif.Media dapat melakukan investigasi keterkaitan antara opini publik dengan urusan luar negeri suatu negara.Hal ini terkait dengan sikap media yang dapat dilihat dalam setiap berita yang dipublikasikan. Intinya bahwa media massa memberikan peranan yang besar terhadap hubungan internasional, termasuk dalam hal mengawal isu-isu internasional dan di arahkan kemana isu-isu tersebut oleh media.

Intinya bahwa dalam perspektif komunikasi internasional, media massa merupakan komunikator paling intens dalam melakukan penyebaran informasi, diusung dari fakta maupun isu internasional dan pembentukan opini publik. Pandangan Prajarto (2003:4) terkait hal ini bahwa pemanggul beban komunikasi internasional yang paling tepat adalah media massa asing atau media massa Indonesia yang berbahasa asing. Namun tidak menutup kemungkinan adanya peran media massa nasional.

Peranan media massa dalam kancah internasional ini sangat dipengaruhi oleh model diplomasi publik secara umum dipahami sebagai upaya untuk mempengaruhi publik internasional (negara lain) demi tercapainya kepentingan nasional suatu negara. Upaya semacam ini dilakukan untuk membentuk suatu jaringan komunikasi sebagai wadah promosi kebijakan luar negeri. Dengan dik- oordinasi oleh pemerintah maupun pihak pihak yang berkepentingan di dalamnya seperti tokoh agama, partai, media massa dan masih banyak lagi. Namun ketika memaknai media massa secara luas, bahwa media massa sebagai sebuah institusi yang menunjukkan eksistensi komunikasi massa dalam sebuah sistem komunikasi internasional, memiliki cara serta fungsi peran dan manfaatnya dalam menterjemahkan hubungan kerjasama antar negara-negara baik yang sedang berkembang maupun yang sudah berkembang.

\section{b. Media Diplomacy}

Senada dengan pandangan di atas bahwa dalam diplomasi publik, pemerintah bukan satu-satunya aktor dalam diplomasi, tetapi terdapat sembilan aktor dalam diplomasi publik.Seperti lembaga swadaya masyarakat, masyarakat, kalangan profesional, pengusaha dan pemilik modal, media, peneliti, akademisi, aktivis, dan kalangan agamawan. Sembilan aktor itu melakukan komunikasi internasional dengan caranya sendiri.Misalnya media massa melakukan diplomasi dengan berbagai liputannya. Banyaknya aktor yang terlibat dalam diplomasi publik memberikan implikasi adanya pengakomodiran informasi dari berbagai aktor guna menjembatani mekanisme diplomasi government to government, people to government, people to people, non government to non government, maupun people and non government to government.

Diplomasi merupakan komunikasi internasional diantara negara-negara yang terlibat dalam aktivitas diplomasi, yang diformulasikan dalam pertukaran permintaan dan konsesi antara para pelaku negosiasi. Namun dengan berfungsinya media massa sebagai aktor diplomasi, tentu segala isuisu internasional yang berkembang sangat ditentukan seberapa besar jangkauan informasi dan koverasi media. Diplomasi bertujuan untuk mencapai kepentingan nasional, keterampilan dalam berdiplomasi merupakan syarat utama sebagai sarana pencapaian kesepakatan, kompromi, dan penyelesaian masalah dimana tujuan-tujuan pemerintah saling bertentangan (Djelantik, 2008: 4). 
Aktivitas media massa dalam komunikasi internasional atau politik internasional memiliki fungsi strategis karena dapat menyatukan semua aktor diplomasi publik melalui fungsi yang dilakukan media massa. Penyatuan aktor berarti media massa mengakomodir pandangan dari aktor tersebut. Misalnya kunjungan diplomatik membahas agenda ekonomi.Tentu idealnya media massa memberitakan pandangan-pandangan aktor bidang ekonomi, seperti akademisi, pemilik modal, pengusaha, dan lainnya.

Rianto (2008:67) menyatakan bahwa media telah mengubah karakteristik umum diplomasi dan politik internasional.Hal ini disebabkan oleh globalisasi media.Bersamaan dengan tuntutan, maka peran media dalam hubungan internasional telah menjadikan para jurnalis dalam meliput peristiwa, mengumpulkan dan menyeleksi fakta, merekonstruksi,serta merepresentasikan realitas membutuhkan waktu yang cepat dan ringkas, padat dalam mewartakan isi tampilan berita yang akan dipublikasikan. Dov Shinar (2000:83) mengatakan bahwa kemampuan media massa dalam menyebarkan pesan-pesan diplomasi dan politik ini, mampu menjadikannya sebagai salah satu instrumen propaganda paling penting. Terkait dengan berita kunjungan diplomatik, media massa tidak hanya sekadar meliput berita, tetapi media massa harus memiliki sikap dalam meliput serta memberikan ruang dan waktu kepada publik untuk menganggap bahwa isu-isu kunjungan diplomatik ini penting untuk dipublikasikan.

Menurut Hariyadi Wirawan (2008:11) bahwa media massa berperan penting dalam membantu masalah-masalah internasional, sehingga media massa juga merupakan bagian yang tidak terpisahkan dari diplomasi internasional. Misalnya peranan media dalam meredakan ketegangan internasional, dalam konteks ke Indonesia-an media harus berperan penting dalam memajukan kepentingan bangsa dan negara Indonesia di kancah internasional sesuai dengan misinya "Million friends, Zero Enemy" (sejuta kawan tanpa musuh). Media sebagai salah satu elemen didalam civil society memiliki peran terdepan untuk mengurangi tensi atau kesalahpahaman yang muncul akibat isu-isu ketegangan antar negara.

Seperti disebutkan oleh pakar ilmu politik Paul Kennedy, bahwa aktor-aktor media massa ikut membentuk dan merubah pola pikir masyarakat. Contoh sederhana adalah besarnya simpati dan dukungan dari masyarakat internasional dan upaya penyelamatan besar-besaran korban tsunami di Aceh pada Desember 2004. Respons spontan dan cepat dari berbagai aktor, pemerintah, Lembaga Swadaya Masyarakat (LSM); individu, tak lepas dari peran media sebagai aktor diplomasi.Substansinya bahwa media massa memiliki kekuatan pengaruh yang sangat besar dalam hal ikut mengendalikan arah perubahan masyarakat, khususnya dalam kerangka politik. Perilaku politik media massa merupakan sesuatu yang menjadi penentu arah perilaku politik masyarakat, baik perilaku mendukung atau menentang (Muhtadi, 2008:51).

Menurut McCombs (1985:119) perubahan sikap suatu masyarakat pada umumnya dipengaruhi oleh adanya informasi baru yang dipandang relevan dengan tuntutan kondisional, kapan dan dimana informasi baru itu diterima.Media massadengan demikian memiliki pengaruh penting dalam proses pembentukan cara berfikir dan berperilaku politik masyarakat.

Hal ini menjadikan media massa memiliki peranan besar dalam hubungan internasional, dalam pengertian yang luas peranannya sebagai katalis dan diplomatic broker (Puji Rianto, 2008: 68). Sebagai diplomatic broker media melaksanakan dan kadang memprakarsai mediasi internasional dalam suatu acara yang seringkali pembedaannya menjadi kabur sebagai reporter atau sebagai seorang diplomat.Akibat peranan yang besar tersebut maka kemudian melahirkan istilah "media diplomacy" (Hachten, 1993:59) yang dalam sejarahnya merujuk pada kasus Walter Cronkite dari CBS dan Barbara Walters dari ABC yang menjadi saluran komunikasi antara Presiden Mesir Anwar Sadat dengan Perdana Menteri Israel Menachem Begin.

Menurut catatan Hachten bahwa 
dampak paling dramatis dicapai oleh stasiun CBS yang berhasil melakukan wawancara sambungan telepon secara terpisah, sedangkan penyiaran dua wawancara tersebut disuting dan disambungkan bersama, sehingga memberikan kesan sedang dilaksanakan wawancara langsung antara kedua pemimpin dengan Cronkite sebagai pewawancaranya. Inilah dimensi baru peranan media dalam politik internasional dewasa ini yang dapat dikatakan sebagai mediator, sehingga pada tataran tersebut media menjembatani yang mungkin juga penuh distorsi dan diplomasi politik antar pejabat politik.

Media massa kadang-kadang dapat memfasilitasi pertemuan bagi para pemimpin politik. Misalnya kesepakatan Anwar Sadat untuk berkunjung ke Yerusalem terjadi setelah wartawan NBC, Walter Cronkite, membawa kedua pemimpin Israel dan Mesir, Anwar Sadat dan Manachem Begin berhasil diwawancarai melalui televisi satelit. Peran media masssa telah disadari sebagai salah satu faktor kunci keberhasilan diplomasi masa kini. Pernyataan Lord Palmerston yang terkenal, opini lebih kuat daripada tentara akan semakin relevan dalam konteks ini.Sama halnya dengan pernyataan Napoleon Bonaparte'sebuah pena lebih berbahaya daripada seribu bayonet". Dua hal tersebut mengandung banyak kebenaran terutama dikaitkan dengan peran media massa pada era reformasi (Djelantik, 2008:70).

Hal ini menjadikan media memiliki peranan besar dalam hubungan diplomatik bahkan hubungan internasional. Bambang Cipto memberikan contoh bahwa media massa Amerika yang memainkan peranan penting dalam mengembangkan dengan cepat pendapat umum tentang pelanggaran hak asasi manusia di Timor Timur.The New York Times memuat editorial yang berjudul "The Tiananmen in East Timor", yang kemudian berita ini menyebabkan suhu politik Amerika Serikat memanas.

Hasil penelitian Disertasi Bambang Cipto (2003: 246-247) "Tekanan Amerika Terhadap Indonesia: Kajian Atas Kebijakan Luar Negeri Clinton Terhadap Indonesia" menilai bahwa media massa Amerika (The New York
Times) meliput berita-berita sesuai dengan kebijakan Amerika tentang pelanggaran hak asasi manusia di Timor Timur. The New York Timesmemberikan dukungan terhadap sikap kritis Amerika terhadap Indonesia dengan melaporkan tindakan-tindakan tak manusiawi yang dilakukan polisi dan tentara Indonesia terhadap penduduk Timor Timur yang beragama Kristen.Sebagaimana ditulis oleh The New York Times, bahwa "perbedaan agama merupakan salah satu penyebab ketegangan hubungan Indonesia dan penduduk Timor Timur, sementara mayoritas penduduk Indonesia Islam, mayoritas penduduk Timor adalah Kristen”.Merujuk pada hasil penelitian tersebut, media massa dapat bersikap mendukung atau bahkan mengkritisi kebijakan politik suatu negara.

\section{Gap Pemahaman Media: Problem Ko- munikasi Politik oleh Media}

Praktik komunikasi dalam politik internasional sering menimbulkan gap.Misalnya kasus film Fitna dan kontroversi pemberitaan akibat publikasi kartun yang sangat melecehkan martabat Nabi Muhammad. Tercatat banyak orang telah menjadi korban sepanjang gelombang kerusuhan dan kekerasan yang terjadi akibat penerbitan kartun ini.Gap-gap ini justru menyebabkan melemahnya hubungan atau politik internasional. Sehingga dalam politik internasional, perkembangan globalisasi media dan jurnalisme internasional perlu untuk melakukan pertukaran perspektif dalam pemberitaannya, makna kebebasan dan hak asasi manusia dalam media massa.

Kasus ini menjadi perhatian internasional karena menyebabkan hampir seluruh negara muslim dan umat muslim marah. Kasus ini bukanlah bentuk kebebasan berekspresi wartawan/media massa. Kebebasan berekpresi pada intinya merupakan sebuah keharusan politis, sosial dan ekonomi, namun kebebasan ini sendiri bukanlah sebuah kebebasan yang tanpa batas.Tiada satu pun kebebasan yang bersifat absolut.

Munculnya gap ini memerlukan pengaturan melalui berbagai kerjasama antara 
negara dalam menata media massa (terutama dalam penyamaan persepsi kebebasan pers). Salah satu kerjasama yang dilakukan Indonesia dengan Pemerintah Kerajaan Norwegia dengan dukungan dari Pemerintah Selandia Baru, menyelenggarakan Global Inter-Media Dialog ke-3 di Bali. Indonesia dan Norwegia sama-sama memandang bahwa dialog global inter media ini sangat penting, mengingat sekarang ini media-media di seluruh dunia tengah menghadapi berbagai tantangan, baik itu dalam segi kontroversi pemberitaan maupun gap mengenai pemahaman kebebasan. Agenda Global Inter-Media Dialog ke-3 diantaranya mencakup: perubahan lanskap media yang sebagian besar merupakan hasil dari kemajuan teknologi informasi dan komunikasi; peliputan atas kelompok minoritas; dan kebenaran-kebenaran yang menyesakkan dada seperti kemiskinan, perang melawan teror, dan perubahan iklim global.

\section{SIMPULAN}

Media dan politik Internasional merupakan dua entitas yang tidak dapat dipisahkan dalam kehidupan modern.Keduanya saling berbagi peran dalam menentukan arah perubahan-perubahan di masyarakat. Hubungan ini dipengaruhi oleh peran besar media massa dalam menentukan derajat keharmonisan dunia internasional, baik dalam hubungan bilateral maupun multilateral. Bagi politik internasional, aktifitas media berperan dalam melaporkan serta memberitakan peristiwa-peristiwa politik, kemudian peristiwa tersebut disampaikan kepada khalayak, untuk selanjutnya publik atau khalayak akan menafsirkan teks-teks berita yang tersaji dalam media tersebut.

Media massa bukan hanya sumber informasi politik, tetapi juga kerap menjadi pendorong (trigger) terjadinya perubahan politik. Secara umum media massa memiliki kecenderungan-kecenderugan tertentu dalam melakukan liputan pada peristiwa politik internasional. Pada posisi seperti inilah, kemudian media massa ditempatkan sebagai kekuatan keempat (the fourth estate) dalam tatanan kehidupan sosial dan politik.
Media berfungsi sebagai pengendali sekaligus melakukan kontrol sosial bagi kepentingan publik.Bahkan, dalam tradisi jurnalisme politik, media adalah pemain (player), subjek aktif di ruang publik bukan sekedar medium atau alat yang dikendalikan pihak diluar pengelola media itu (Rosen, 2004). Sebagai pemain tentu berfungsi sebagai agen perubahan (agent of change) pada level internasional dengan menggunakan caranya sendiri, yakni melalui publikasi berita politik yang menjadi agenda politiknya.

Dalam wujud yang lebih konkret, media memiliki peranan besar dalam komunikasi politik internasional.Keterlibatan aktif media ini telah melahirkan istilah "media diplomacy". Media massa sebagai saluran dalam menjalankan misi diplomasi sebuah negara tehadap negara lainnya. Sebagai "media diplomacy”, media massa tidak hanya sekadar meliput peristiwa diplomatik, tetapi media massa harus bersikap sebagai seorang negosiator. Terkait dengan media diplomacy bahwa media sebagai salah satu aktor dalam dinamika tata hubungan internasional, dan posisi Indonesia dalam tata hubungan internasional sangat dipengaruhi aktor media massa tersebut. 


\section{DAFTAR PUSTAKA}

Canggara, Hafied. 2009.Komunikasi Politik: Konsep, Teori, dan Strategi. Jakarta: Rajawali Pers.

Cipto, Bambang. 2003, Tekanan Amerika Terhadap Indonesia: Kajian Atas Kebijakan Luar Negeri Clinton Terhadap Indonesia. Yogyakarta: Pustaka Pelajar.

Djelantik, Sukawarsini. 2008.Diplomasi: Antara Diplomasi dan Praktik. Yogyakarta: Graha Ilmu.

Eriyanto.200o, Analisis Framing, Konstruksi Ideologi dan Politik Media.Yogyakarta: LKiS.

Hachten, William. 1993.Komunikasi Internasional. Bandung: Remaja Rosdakarya.

Hamad, Ibnu. 2004.Konstruksi Realitas Politik dalam Media Massa: Sebuah Studi Critical Analysis Discourses Terhadap Berita-BeritaPolitik. Jakarta: Granit. . 2005, "Media Above The Line dan Below The Line dalam Pilkada", Jurnal Desentralisasi Volume 6 Nomor 4, Pusat Kajian Kinerja Otonomi Daerah, Lembaga Administrasi Negara, Jakarta.

McNair, Brian. 1995.An introduction to Political Communication. London: Routledge.

McQuails, Dennis. 2002.McQuails Mass Communication Theory.London: Sage Publication.

Mosco, Vincent. 1998.The Political Economy of Communication: Rethinking and Renewal. London, Sage Publication.

Muhtadi, Asep Saeful. 2008.Komunikasi Politik Indonesia: Dinamika Islam Politik Pasca Orde Baru. Bandung: Rosdakarya.

Muis, A. 2000, Titian Jalan Demokrasi: Peranan Kebebasan Pers untuk Budaya Komunikasi Politik. Jakarta: Kompas.

Nimmo, Dan. 2006 Komunikasi Politik: Komunikator, Pesan dan Media. Bandung: Remaja Rosda Karya.
Rianto, Puji. 20o8. "Globalisasi Media dan Transformasi Politik Internasional, Jurnal Ilmu Komunikasi, Volume 5 Nomor 1.

Rantanen, Terhi. 2006. The Media and Globalization. London: Thausand Oaks.

Rudi, T. May. 2005.Komunikasi dan Hubungan Masyarakat Internasional. Bandung: Refika Aditama.

Shoelhi, Muhammad. 2009.Komunikasi Internasional PerspektifJurnalistik. Bandung: Simbiosa Rekatama Media.

. 2011.Diplomasi: Praktik Komunikasi Internasional. Bandung: Simbiosa Rekatama Media.

Siregar, Ashadi. 200o."Media Pers dan Negara: Keluar dari Hegemoni”, Jurnal Ilmu Sosial dan Ilmu Politik Volume 4, Nomor 2.

Sudibyo, Agus. 20o1. Politik Media dan Pertarungan Wacana.Yogyakarta: LKiS.

Wahyuni, Hermin Indah. 20oo. "Relasi Media-Negara-Masyarakat dan Pasar Dalam Era Reformasi”.Jurnal Ilmu Sosial dan Ilmu Politik, Volume 4 Nomor 2. 2008."Kecenderungan "Framing" Media Massa Indonesia dalam Meliput Bencana Sebagai Media Event".Jurnal Ilmu Sosial dan Ilmu Politik, Volume 11, Nomor 3. 
INFORMASI Kajian Ilmu Komunikasi Volume 45. Nomor 1. Juni 2015 